\title{
Clinical significance of epidermal growth factor receptor mutations and insulin-like growth factor 1 and its binding protein 3 in advanced non-squamous non-small cell lung cancer
}

\author{
KATSUHIRO MASAGO ${ }^{1}$, SHIRO FUJITA ${ }^{2}$, YOSUKE TOGASHI ${ }^{1}$, YOUNG HAK KIM ${ }^{1}$, \\ YUKIMASA HATACHI ${ }^{1}$, AKIKO FUKUHARA ${ }^{1}$, HIROKI NAGAI $^{1}$, KAORU IRISA ${ }^{1}$, \\ YUICHI SAKAMORI $^{1}$, TADASHI MIO ${ }^{2}$ and MICHIAKI MISHIMA ${ }^{1}$
}

${ }^{1}$ Department of Respiratory Medicine, Graduate School of Medicine, Kyoto University, Kyoto;

${ }^{2}$ Division of Integrated Oncology, Institute of Biomedical Research and Innovation, Kobe, Japan

Received December 15, 2010; Accepted February 21, 2011

DOI: $10.3892 /$ or.2011.1354

\begin{abstract}
This study of patients with advanced non-squamous non-small cell lung cancer (NSCLC) evaluated epidermal growth factor receptor (EGFR) mutation status and two serum markers, serum insulin-like growth factor 1 (IGF1) and IGF binding protein 3 (IGFBP3), for their associations to response to gefitinib therapy and for their prognostic impact. An immunoradiometric assay determined levels of IGF1 and IGFBP3 in serum from 68 patients with advanced non-squamous NSCLC. The peptic nucleic acid locked nucleic acid clamp method determined their EGFR somatic mutation status. We evaluated the relationship between each independent clinicopathological variable and the response to gefitinib therapy and the risk factors associated with prognosis. Having IGF1-positive serum as determined by the 75th percentile and having wild-type EGFR were both independent negative predictive factors for geftinib treatment by multivariate logistic regression model analysis. Both having serum positive for IGF1 as determined by the 25th percentile and having wild-type EGFR were significant independent negative prognostic factors for survival based on multivariate analysis. We demonstrated that having IGF1-positive serum predicts a negative response to gefitinib therapy independent of EGFR mutational status. We also demonstrated that both IGF1positive serum and wild-type EGFR were independent poor prognostic factors in patients with non-squamous NSCLC who received gefitinib therapy.
\end{abstract}

Correspondence to: Dr Katsuhiro Masago, Department of Respiratory Medicine, Graduate School of Medicine, Kyoto University, 54 Shogoin-Kawaracho, Sakyo-ku, Kyoto 606-8507 Japan

E-mail: masago@kuhp.kyoto-u.ac.jp

Key words: gefitinib, insulin-like growth factor 1, insulin-like growth factor-binding protein-3, epidermal growth factor receptor somatic mutation, non-small cell lung cancer

\section{Introduction}

Lung cancer, a major cause of cancer-related mortality worldwide, is expected to remain a major health problem for the foreseeable future. Chemotherapy is the cornerstone of management of the disease. However, its therapeutic impact on patient survival has been modest. Recent discoveries have provided a greater understanding of the molecular basis of the disease. These have yielded successes in treating advanced non-small cell lung cancer (NSCLC) through the two small molecule tyrosine kinase inhibitors (TKIs), gefitinib and erlotinib, against epidermal growth factor receptor (EGFR) (1-4) and through the monoclonal antibody to vascular endothelial growth factor, bevacizumab (5). Many reports have indicated that EGFR-TKIs have significant efficacy in specific subgroups of patients, including Asians, patients with adenocarcinomas, non-smokers, and women $(3,4,6)$. The presence of somatic mutations in the EGFR is a strong predictor for both clinical and in vitro sensitivity to EGFRTKIs (1-4,7-18).

Insulin-like growth factors (IGFs) are mitogens that have a critical role in the regulation of cell proliferation, differentiation and apotosis (19). The actions of IGFs are dependent on the presence of a specific cell surface receptor, the IGF1 receptor (IGF1R). The interaction between IGFs and IGF1R is regulated by IGF binding proteins (BP), with at least $90 \%$ of circulating IGF1 bound to IGFBP3, which is the major binding protein in plasma (20). Recent epidemiological studies have shown that high levels of serum IGF1 are associated with an increased risk of cancer (21-35), but very few studies have addressed the association of the serum levels of IGF1 and IGFBP3 with the survival time of patients with advanced NSCLC.

The IGF1R pathway has also been shown to exhibit cross-talk with a number of other signaling pathways including EGFR pathways. Targeting IGF-IR/IR signaling with BMS-754807, which is a potent and reversible small-molecule TKI of the IGF-IR/IR family kinases having a wide spectrum of antitumor efficacy (36), has resulted in cancer cell growth inhibition both in vitro and in vivo. This drug is currently in 
Table I. Associations between NSCLC patient characteristics and responses to gefitinib therapy $(n=68)$.

\begin{tabular}{|c|c|c|c|c|}
\hline Variables & Total $(n=68)$ & $\begin{array}{l}\text { DC [disease controlled cases; } \\
\quad(30 \mathrm{PR}+12 \mathrm{SD})](\mathrm{n}=42)\end{array}$ & $\mathrm{PD}(\mathrm{n}=26)$ & P-value \\
\hline \multicolumn{5}{|l|}{ Gender } \\
\hline Male (\%) & $30(44.1)$ & 16 & 14 & NS \\
\hline Female (\%) & $38(55.9)$ & 26 & 12 & \\
\hline \multicolumn{5}{|l|}{ Age (years) } \\
\hline Median & 67 & & & \\
\hline Range & $34-82$ & & & \\
\hline$<70$ & $40(70.6)$ & 25 & 15 & NS \\
\hline$\geq 70$ & $28(41.2)$ & 17 & 11 & \\
\hline \multicolumn{5}{|l|}{ Histological type } \\
\hline Adenocarcinoma (\%) & $62(91.2)$ & 40 & 22 & NS \\
\hline $\operatorname{NSCLC}(\%)$ & $6(8.8)$ & 2 & 4 & \\
\hline \multicolumn{5}{|l|}{ Disease stage } \\
\hline IIIB $(\%)$ & $16(23.5)$ & 14 & 2 & $0.01^{\mathrm{a}}$ \\
\hline $\operatorname{IV}(\%)$ & $52(76.5)$ & 28 & 24 & \\
\hline \multicolumn{5}{|l|}{ ECOG PS } \\
\hline $0-1(\%)$ & $63(92.6)$ & 40 & 23 & NS \\
\hline$\geq 2(\%)$ & $5(7.4)$ & 2 & 3 & \\
\hline \multicolumn{5}{|c|}{ First line therapy with Gefitinib } \\
\hline Yes $(\%)$ & $19(27.9)$ & 14 & 5 & NS \\
\hline No $(\%)$ & $49(72.1)$ & 28 & 21 & \\
\hline \multicolumn{5}{|l|}{ Smoking history } \\
\hline Never $(\%)$ & $40(58.8)$ & 26 & 14 & NS \\
\hline Former $(\%)$ & $17(25.0)$ & 12 & 5 & \\
\hline Current $(\%)$ & $11(16.2)$ & 4 & 7 & \\
\hline \multicolumn{5}{|c|}{ Serum IGF1 (25th percentile) } \\
\hline Positive $(\%)$ & $51(75.0)$ & 32 & 19 & NS \\
\hline Negative (\%) & $17(25.0)$ & 10 & 7 & \\
\hline \multicolumn{5}{|c|}{ Serum IGF1 (50th percentile) } \\
\hline Positive $(\%)$ & $34(50.0)$ & 22 & 12 & \\
\hline Negative (\%) & $34(50.0)$ & 20 & 14 & \\
\hline \multicolumn{5}{|c|}{ Serum IGF1 (75th percentile) } \\
\hline Positive (\%) & $17(25.0)$ & 7 & 10 & $0.0459^{\mathrm{a}}$ \\
\hline Negative (\%) & $51(75.0)$ & 35 & 16 & \\
\hline \multicolumn{5}{|l|}{ Serum IGF1 $1^{\mathrm{a}}$} \\
\hline Positive (\%) & $38(55.9)$ & 26 & 12 & NS \\
\hline Negative (\%) & $30(44.1)$ & 16 & 14 & \\
\hline \multicolumn{5}{|c|}{ Serum IGFBP3 (25th percentile) } \\
\hline Positive $(\%)$ & $52(76.4)$ & 32 & 20 & NS \\
\hline Negative (\%) & $16(23.6)$ & 10 & 6 & \\
\hline \multicolumn{5}{|c|}{ Serum IGFBP3 (50th percentile) } \\
\hline Positive $(\%)$ & $34(50.0)$ & 20 & 14 & NS \\
\hline Negative (\%) & $34(50.0)$ & 22 & 12 & \\
\hline \multicolumn{5}{|c|}{ Serum IGFBP3 (75th percentile) } \\
\hline Positive $(\%)$ & $17(25.0)$ & 11 & 6 & NS \\
\hline Negative (\%) & $34(75.0)$ & 31 & 20 & \\
\hline \multicolumn{5}{|l|}{ Serum IGFBP $3^{b}$} \\
\hline Positive (\%) & $36(52.9)$ & 21 & 15 & NS \\
\hline Negative $(\%)$ & $32(47.1)$ & 21 & 11 & \\
\hline
\end{tabular}


Table I. Continued.

\begin{tabular}{|c|c|c|c|c|}
\hline Variables & Total $(n=68)$ & $\begin{array}{l}\mathrm{DC} \text { [disease controlled cases; } \\
\quad(30 \mathrm{PR}+12 \mathrm{SD})](\mathrm{n}=42)\end{array}$ & $\mathrm{PD}(\mathrm{n}=26)$ & P-value \\
\hline \multicolumn{5}{|l|}{ EGFR mutation $^{\mathrm{c}}$} \\
\hline Positive (\%) & $38(55.9)$ & 30 & 8 & \multirow[t]{2}{*}{$0.0009^{\mathrm{a}}$} \\
\hline Wild-type (\%) & $30(44.1)$ & 12 & 18 & \\
\hline \multicolumn{5}{|c|}{ Activating EGFR mutation } \\
\hline Exon 21 L858R (\%) & $20(52.6)$ & $12 \mathrm{PR}+5 \mathrm{SD}$ & 3 & \multirow[t]{2}{*}{ NS } \\
\hline Exon 19 del $(\%)$ & $18(47.4)$ & $12 \mathrm{PR}+1 \mathrm{SD}$ & 5 & \\
\hline
\end{tabular}

phase I development for the treatment of a variety of human cancers; preclinically defined efficacious exposures have been achieved with p.o. administration of single, tolerable doses in humans (37) and effects of BMS-754807 on pharmacodynamic biomarkers have been observed in cancer patients (38).

To the best of our knowledge, there are no reports evaluating the effects of IGF1 and IGFBP3 on EGFR pathways. We hypothesized that serum IGF1 and IGFBP3 may be surrogate markers for response to gefitinib, independent of EGFR mutational status, and may be involved in the development of NSCLC. In this study, we retrospectively examined the association between serum IGF1 and IGFBP3, and the response to gefitinib of patients with advanced NSCLC as well as evaluated their prognostic impact.

\section{Materials and methods}

Study population. Sixty-eight patients with advanced nonsquamous NSCLC who were treated with gefitinib between December 2003 and November 2009 at Kyoto University Hospital were enrolled in this study. The Standard Response Evaluation Criteria in Solid Tumors was used for response evaluation. Trans-bronchial specimens from all patients were available for analysis of EGFR somatic mutations. Serum samples were collected from all the subjects before treatment with gefitinib and stored at $-80^{\circ} \mathrm{C}$. Written informed consent pertaining to the utilization of clinical materials was obtained from all patients. The Ethics Committee of Kyoto University Hospital approved the study, and it conforms to the provisions of the Declaration of Helsinki in 1995.

Immunoradiometric assay of IGF1 and IGFBP3. All the samples were assayed by trained staff at a single laboratory (The SRL, Inc., Hachioji, Japan). Serum levels of IGF1 and IGFBP3 were measured by immuno-radiometric assay using commercially available kits (Daiichi Radioisotope Laboratories, Tokyo). The mean intra-assay coefficient of variation on quality control serum samples was $2.3 \%$ for IGF1 and $8.7 \%$ for IGFBP3. The range of reliable measurement was
4-2,000 $\mathrm{ng} / \mathrm{ml}$ for IGF1, and 0.07-10.10 $\mu \mathrm{g} / \mathrm{ml}$ for IGFBP3. The intra- and inter-assay coefficients of variation were 2.153.53 and $1.21-4.11 \%$ for IGF1 and 3.16-4.19 and 5.28-8.89\% for IGFBP3, respectively.

Analysis of EGFR somatic mutations. DNA was extracted from cancer cells obtained from paraffin-embedded biopsy specimens by manual micro-dissection using a modification of the phenolchloroform extraction method $(13,14)$. Briefly, tissues that had been formalin-fixed and paraffin-embedded were cut into $5 \mu \mathrm{m}$ sections and mounted on pretreated glass slides. One slice was used to confirm the presence of cancer cells under a microscope and the others were for DNA analyses. Non-cancer cells and necrotic portions were manually removed from the slide under the microscope. The slides were deparaffinized and DNA was extracted by precipitation with phenolchloroform and ethanol.

To detect EGFR mutations in the large background of wild-type EGFR genes derived from normal cells, we adopted the peptic nucleic acid locked nucleic acid (PNA-LNA) polymerase chain reaction (PCR) clamp method (39). Briefly, PNA clamp primers inhibit amplification of the wild-type sequence, and LNA probes are used to specifically detect mutant sequences in the presence of wild-type sequences. A synergic effect of these primers causes specific PCR amplification of mutant sequences. Specific PNA-LNA probe sets to each mutation were developed to cover $>95 \%$ of the EGFR mutations previously reported in Japan (40). PCR products from both conventional PCR and the PNA-LNA PCR were purified and directly sequenced on an ABI PRISM 3100 automated capillary sequencer in both the sense and antisense directions.

Statistical analysis. The univariable relationship between each independent variable was examined using either the $\chi^{2}$ test or the Fisher's exact test. A multivariable logistic regression model was applied to estimate odds ratios (ORs) and $95 \%$ confidence intervals (CI). Only those variables with P-values $<0.10$ by univariable analysis were included in the multivariable analysis. All tests were two-tailed and 

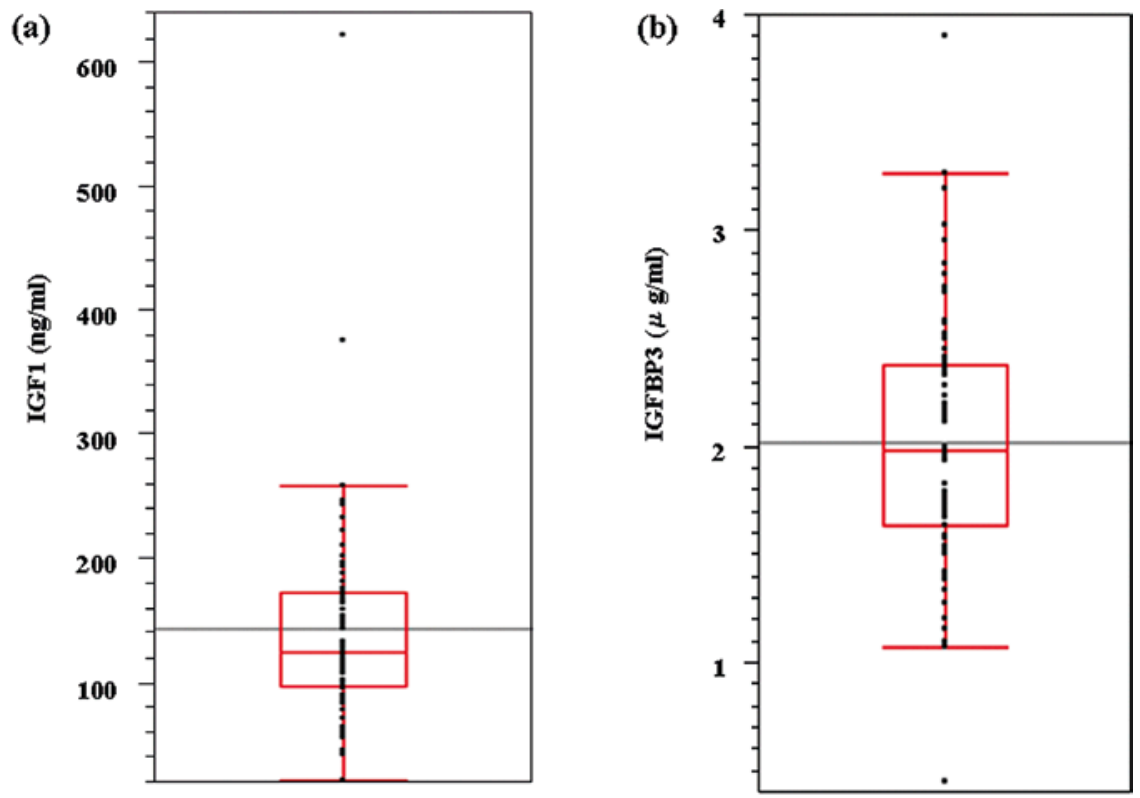

Figure 1. An immuno-radiometric assay of the serum from the 68 patients treated with gefitinib determined the concentrations of (a) insulin-like growth factor 1 (IGF1) and (b) IGF binding protein 3 (IGFBP3).
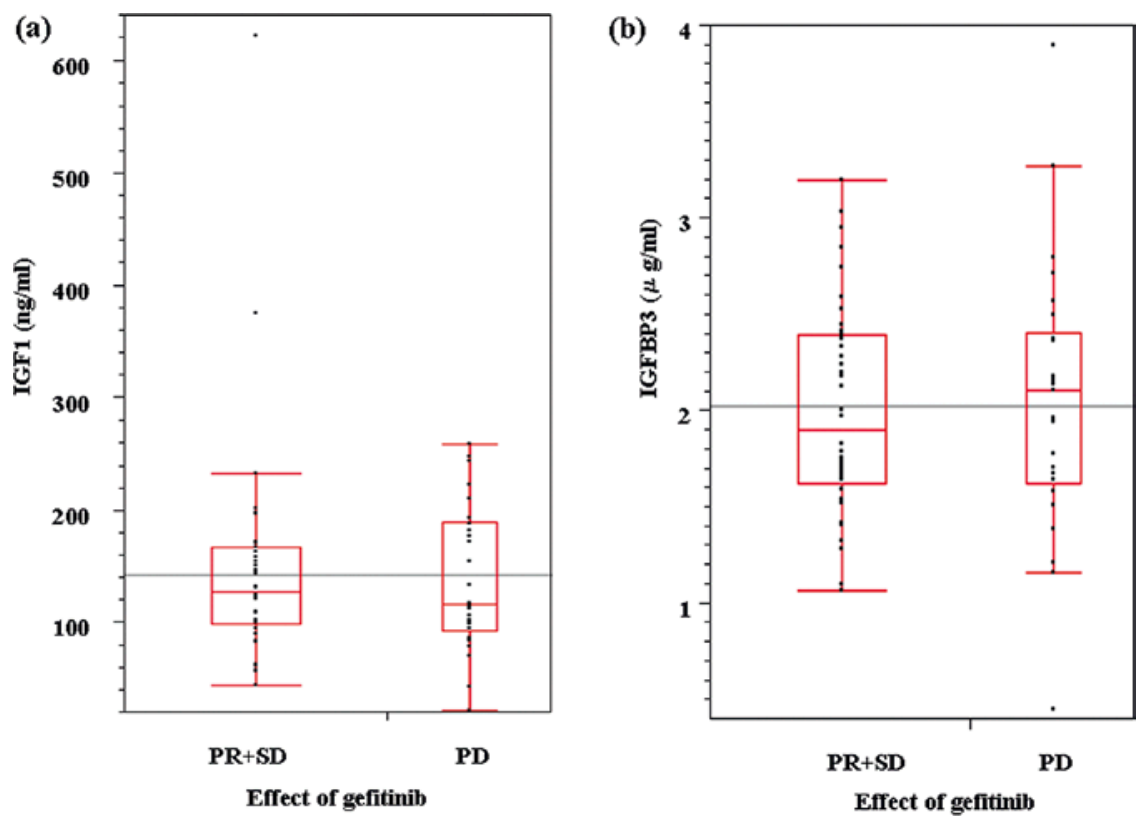

Figure 2. An immuno-radiometric assay of the serum concentrations of (a) insulin-like growth factor 1 (IGF1) and (b) IGF binding protein 3 (IGFBP3) from 68 patients analyzed by their response to gefitinib therapy. Responses to gefitinib therapy were either disease controlled (DC), which included partial response $(\mathrm{PR})$ and stable disease (SD), or progression disease (PD).

P-values $<0.05$ were considered statistically significant. To evaluate risk factors associated with prognosis, a Cox proportional hazards regression model with a step-down procedure was used. Proportional hazards assumptions were checked and satisfied; only those variables with statistically significant results in the univariate analysis were included in the multivariate analysis. The criterion for removing a variable was the likelihood ratio statistic, which was based on the maximum partial likelihood estimate (default P-value of 0.05 for removal from the model). Survival time was calculated from the date of diagnosis. Survival curves were determined using the Kaplan-Meier method. The log-rank test allowed us to evaluate the differences between survival curves. All preceding statistical analyses were performed using JMP 6 software (SAS Institute, Cary, NC, USA).

\section{Results}

The characteristics of the 68 enrolled patients are shown in Table I. All the patients were Japanese, treated with $250 \mathrm{mg}$ gefitinib daily, and had a median age of 67 years (range $34-82)$, comprising $30(44.1 \%)$ men and 38 (55.9\%) women. 

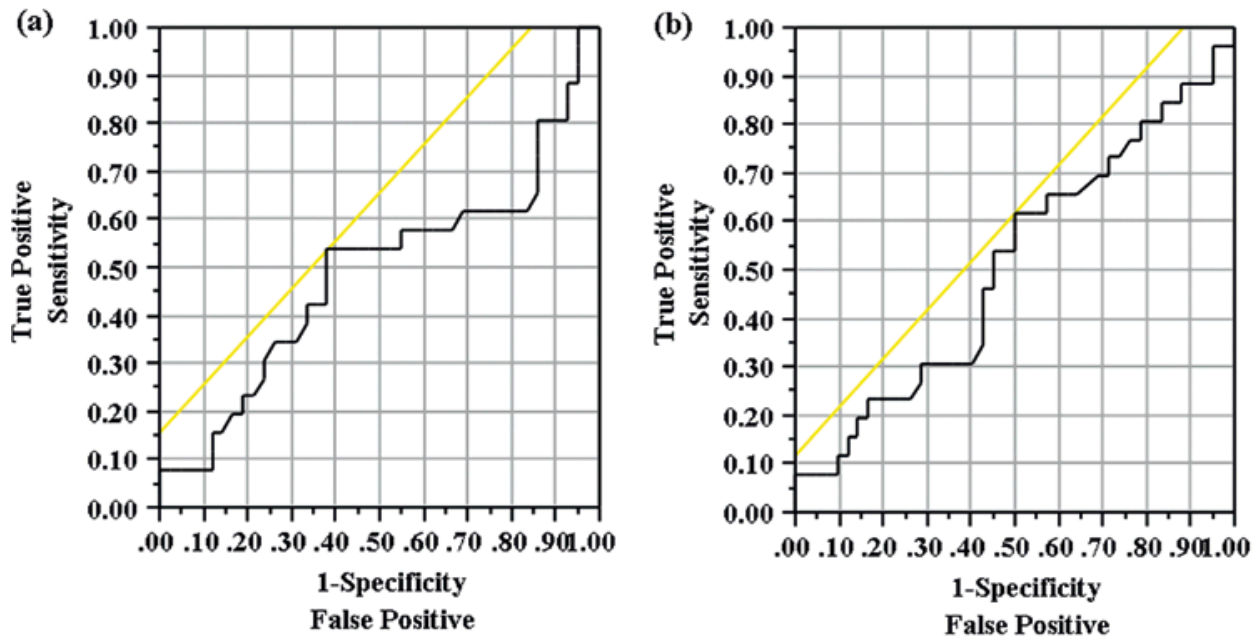

Figure 3. Progressive disease (PD) cases were discriminated from disease-controlled (DC) cases through receiver-operated characteristic (ROC) curves drawn according to the optimal diagnostic accuracy and likelihood ratios of (a) insulin-like growth factor 1 (IGF1) (AUC $=0.4881$ ), (b) IGF binding protein 3 $(\mathrm{IGFBP3})(\mathrm{AUC}=0.5077)$.

Table II. Association between patient characteristics and the effects of gefitinib therapy.

\begin{tabular}{lcc}
\hline Variables & Odds ratio (95\% CI) & P-value \\
\hline Multivariate analysis & & \\
Disease stage (IV/IIIB) & $4.58(1.78-35.13)$ & 0.0643 \\
Serum IGF1 (75th percentile) (Positive/Negative) & $3.94(1.45-18.33)$ & $0.0484^{\mathrm{a}}$ \\
EGFR mutation (Wild-type/Mutated) & $8.41(2.54-34.42)$ & $0.0003^{\mathrm{a}}$ \\
\hline
\end{tabular}

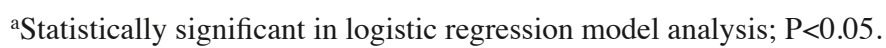

Enrolled patients had either adenocarcinoma $(n=62,91.2 \%)$ or unspecified NSCLC $(n=6,8.8 \%)$. Forty $(58.8 \%)$ patients were non-smokers and $28(41.2 \%)$ patients were former or current smokers. The Eastern Cooperative Oncology Group (ECOG) performance status (PS) was $0-1$ for 63 patients and $>2$ for 5 patients. A total of $49(72.1 \%)$ patients had been treated with at least two regimens of chemotherapy and 19 (27.9\%) patients had received gefitinib therapy as the first-line regimen.

The serum levels of IGF1 and IGFBP-3 are shown in Fig. 1. Positive or negative serum markers were determined by the cut-off values of $118.0 \mathrm{ng} / \mathrm{ml}$ for serum IGF1 and $1.94 \mu \mathrm{g} / \mathrm{ml}$ for serum IGFBP3. These cut-off values were set by drawing receiver-operated characteristic (ROC) curves according to optimal diagnostic accuracy and likelihood ratios. These ratios discriminated progressive disease (PD) cases from disease-controlled (DC) cases [partial response $(\mathrm{PR})+$ stable disease (SD)] (Figs. 2-3). The positive or negative serum haemostatic parameters were also determined by the cut-off values for the 25 th, 50 th, and 75 th percentiles, which were $96.75,124.50$, and $172.75 \mathrm{ng} / \mathrm{ml}$ for serum IGF1 and $1.64,1.98$, and $2.38 \mu \mathrm{g} / \mathrm{ml}$ for serum IGFBP-3. Positive EGFR somatic mutations include L858R in exon 21, and del 746-750 and del 752-759 in exon 19.

The associations between clinicopathological factors and responses to gefitinib therapy are shown in Table I. Of the 26 PD cases, $10(38.5 \%)$ were positive for IGF1 as determined by the 75 th percentile, whereas $35(83.3 \%)$ of the $42 \mathrm{DC}$ cases were negative $(\mathrm{P}=0.0459$ by Fisher's exact test). Of the 26 PD cases, 18 (69.2\%) had wild-type EGFR, whereas 30 $(71.4 \%)$ of the 42 DC cases had EGFR mutations $(\mathrm{P}=0.0009$ by Fisher's exact test). Of the 26 PD cases, 24 (92.3\%) were stage IV, whereas $14(33.3 \%)$ of the 42 DC cases were stage IIIB ( $\mathrm{P}=0.001$ by Fisher's exact test). Of the three factors analyzed, having IGF1-positive serum as determined by the 75th percentile (OR, 3.94; 95\% CI, 1.45-18.33; $\mathrm{P}=0.484)$ and having wild-type EGFR (OR, 8.41; 95\% CI, 2.54-43.42; $\mathrm{P}=0.0003$ ) were found to be independent negative predictive factors for geftinib treatment by multivariate logistic regression model analysis (Table II).

The median survival time of the patients with IGF1positive serum was significantly shorter than those whose plasma serum was IGF1-negative $(\mathrm{P}=0.0399$ by log-rank test; Fig. 4). Likewise, patients with mutated EGFR had a better median survival time than those with wild-type EGFR $(\mathrm{P}=0.025$ by log-rank test; Fig. 5$)$. Data were available from 68 patients for a Cox regression analysis to determine the correlation between patient prognosis and the clinicopathological factors of age ( $<70 \mathrm{vs}$. $\geq 70$ years), gender (male vs. female), smoking history (smoker vs. never smoker), PS (>2 vs. 0-1), disease stage (IV vs. IIIB), histology (non-adeno vs. adeno), EGFR (wild-type vs. positive), first line therapy with gefitinib (yes vs. no), serum IGF1 status (positive vs. 


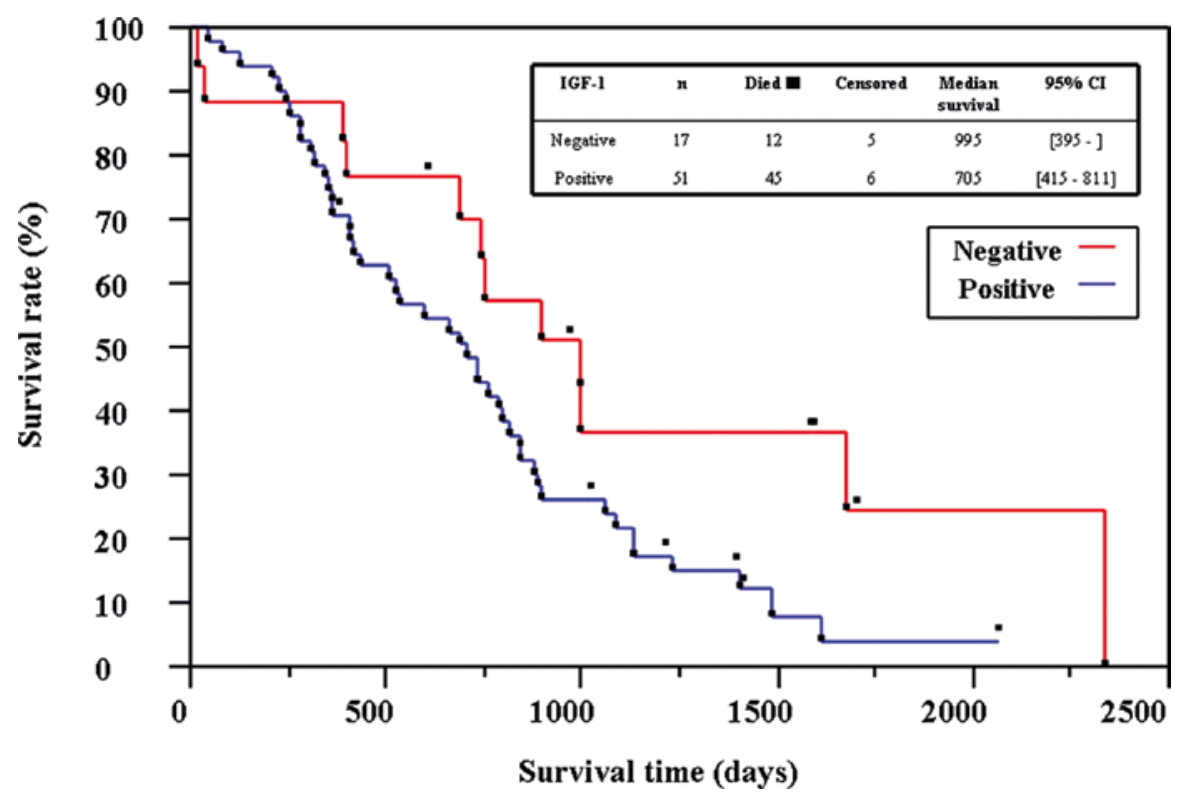

Figure 4. The survival of 68 gefitinib-treated patients was related to their insulin-like growth factor 1 (IGF1) status by Kaplan-Meier analysis. The patients whose serum was positive for IGF-1 are represented by the blue line and those whose was negative by the red line. The differences between the groups were evaluated with the log-rank test $(\mathrm{P}=0.0399)$.

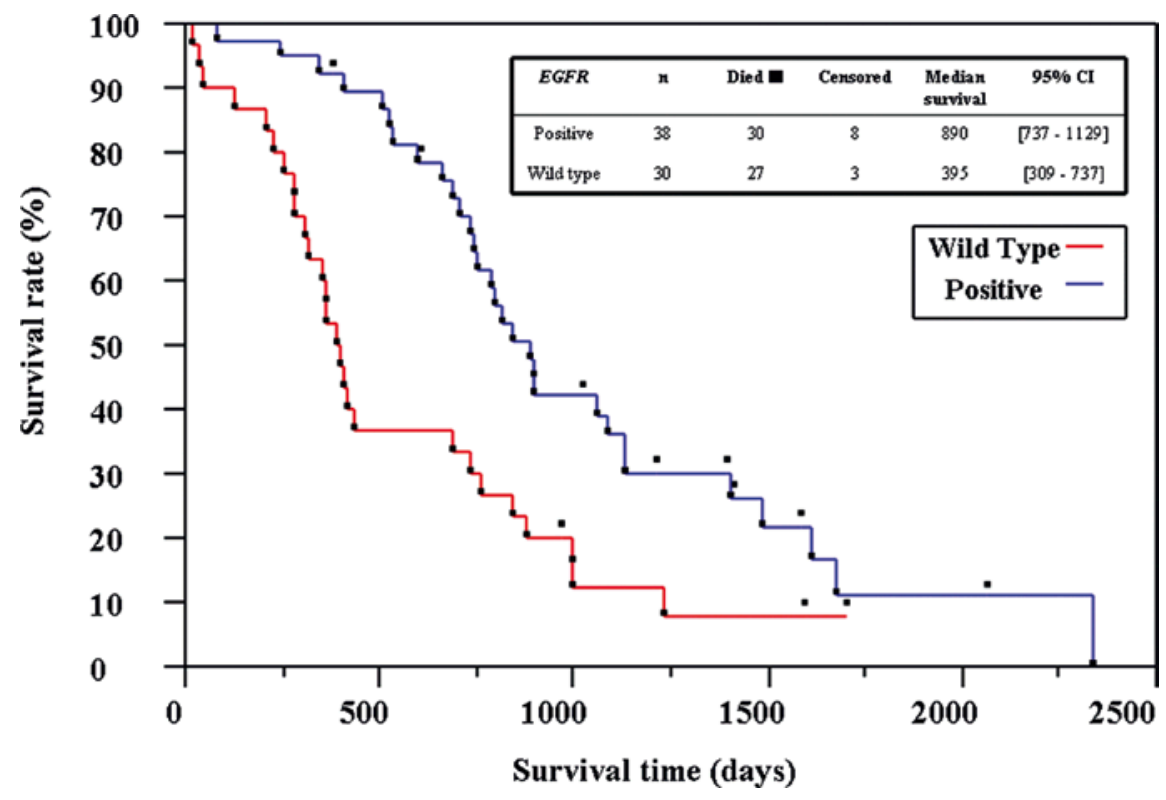

Figure 5. The survival of 68 gefitinib-treated patients was related to their epidermal growth factor receptor (EGFR) mutation status by Kaplan-Meier analysis The patients with the wild-type EGFR are indicated by the red line and those with EGFR mutations by the blue line. The differences between the groups were evaluated with the log-rank test $(\mathrm{P}=0.0025)$.

negative), and serum IGFBP3 status (positive vs. negative) (Table III). Among these factors, EGFR mutational status (HR, 1.490; 95\% CI, 1.140-1.944 P=0.0038) and IGF1positive serum status as determined by the $25 \%$ percentile (HR, 1.414; 95\% CI, 1.029-2.030; $\mathrm{P}=0.0320$ ) had significant prognostic effects on survival based on univariate analysis. Based on multivariate analysis, wild-type EGFR (HR, 1.691; 95\% CI, 1.276-2.240; $\mathrm{P}=0.0003$ ) and IGF1-positive serum as determined by the 25 th percentile (HR, $1.664 ; 95 \% \mathrm{CI}$, $1.190-2.429 ; \mathrm{P}=0.0023$ ) were significant independent negative prognostic factors for survival.

\section{Discussion}

We found that having serum positive for IGF1 and having wild-type EGFR are independent predictors of poor response to gefitinib therapy. We showed that these same factors are independent factors for poor prognosis in survival of patients with advanced NSCLC who were consequently treated with gefitinib.

The IGF1R pathway has been shown to exhibit cross-talk with a number of other signaling pathways, suggesting a possible role in mediating resistance to therapeutics targeting 
Table III. Cox proportional hazards model analysis of prognostic factors in patients with advanced NSCLC who consequently treated with gefitinib $(n=68)$.

\begin{tabular}{|c|c|c|}
\hline Variables & Hazard ratio $(95 \% \mathrm{CI})$ & P-value \\
\hline \multicolumn{3}{|l|}{ Univariate analysis } \\
\hline Age $(<70 / \geq 70)$ & $1.068(0.820-1.403)$ & 0.6289 \\
\hline Gender (Male/Female) & $1.024(0.786-1.341)$ & 0.8635 \\
\hline Smoking history (Smoker/Never smoker) & $1.133(0.862-1.481)$ & 0.3662 \\
\hline $\mathrm{PS}(\geq 2 / 0-1)$ & $1.528(0.836-2.416)$ & 0.1498 \\
\hline Disease Stage (IV/IIIB) & $1.040(0.771-1.451)$ & 0.8052 \\
\hline Histology (Non-adeno/Adeno) & $1.540(0.946-2.295)$ & 0.0787 \\
\hline EGFR mutation (Wild-type/Positive) & $1.490(1.140-1.944)$ & $0.0038^{\mathrm{a}}$ \\
\hline First-line therapy with gefitinib (Yes/No) & $1.175(0.866-1.558)$ & 0.2899 \\
\hline Serum IGF1 (25th percentile) (Positive/Negative) & $1.414(1.029-2.030)$ & $0.0320^{\mathrm{a}}$ \\
\hline Serum IGF1 (50th percentile) (Positive/Negative) & $1.133(1.487-6.527)$ & 0.3601 \\
\hline Serum IGF1 (75th percentile) (Positive/Negative) & $1.299(1.029-2.030)$ & 0.1018 \\
\hline Serum IGF1 (Positive/Negative) & $1.189(0.908-1.573)$ & 0.2085 \\
\hline Serum IGFBP3 (25th percentile) (Negative/Positive) & $1.140(0.833-1.512)$ & 0.3984 \\
\hline Serum IGFBP3 (50th percentile) (Negative/Positive) & $1.040(0.797-1.357)$ & 0.7727 \\
\hline Serum IGFBP3 (75th percentile) (Positive/Negative) & $1.411(0.833-1.521)$ & 0.3974 \\
\hline Serum IGFBP3 (Negative/Positive) & $1.041(0.795-1.359)$ & 0.7661 \\
\hline \multicolumn{3}{|l|}{ Multivariate analysis } \\
\hline EGFR mutation (Wild-type/Mutated) & $1.691(1.276-2.240)$ & $0.0003^{\mathrm{a}}$ \\
\hline Serum IGF1 (25th percentile) (Positive/Negative) & $1.664(1.190-2.429)$ & $0.0023^{\mathrm{a}}$ \\
\hline
\end{tabular}

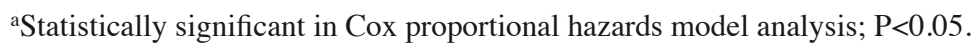

these other pathways. In particular, up-regulated IGF1R expression in response to an EGFR inhibitor results in sustained activation of the PI3K pathway and resistance to the cytotoxic and anti-invasive effects of EGFR inhibition (41). In addition, it has been shown that cell lines with an epithelial phenotype and strong dependence on AKT signaling have strongly synergistic effects both in vitro and in vivo when EGFR and IGF1R inhibition are combined (42). Similar synergistic effects have been reported when an EGFR inhibitor was combined with the IGF1R TKI BMS-536924 in a panel of sarcoma cell lines (43). Our result that IGF1-positive serum was a predictor of poor response to gefitinib therapy may confirm previous findings that an up-regulated IGF1R pathway causes resistance to gefitinib through the inhibition of the EGFR pathway. Also, serum IGF1 may be a surrogate marker of activated IGF1R pathway.

At the cellular level, IGF1 and its binding proteins have effects on cell proliferation, differentiation, and the prevention of apoptosis through the activation of various intracellular signaling pathways, including the Ras/Raf/MAP kinase and the phosphoinositide-3 kinase pathways (44). Several studies have shown the serum concentrations of IGF1 and IGFBP3 to be linked with increased risks of breast (21-23), prostate (24-26), colorectal (27-29), ovarian $(30,31)$, and pancreatic cancer (32-35). For lung cancer, Yu et al (45) reported that the relative risk of lung cancer for the interquartile range of IGF1 serum concentrations was 2.0. After adjustment for IGFBP3, the odds ratio was 2.75. However, the New York University Women's Health Study Cohort could not find an association between serum IGF1, IGFBP1, IGFBP2, and IGFBP3 and lung cancer in women (46). Most studies have focused on the risk of cancer relative to the plasma concentrations of IGF1 and IGFBP3. There have been no reports evaluating the prognostic impact of serum IGF1 and IGFBP3, especially in advanced lung cancer patients. In our study, having IGF1positive serum indicated a poor prognosis independent of EGFR mutational status. This result may be explained by the up-regulated IGF1R pathway, which proliferates and prevents apoptosis such as in pancreatic cancer (47) and induces the resistance of EGFR-TKIs.

IGFBP3 is a key determinant of the availability and actions of IGF1, and it is also a potent antiproliferation agent in the cellular environment (48). To date, most epidemiological studies examining cancer risk relative to IGFBP3 have demonstrated that lower serum levels increase cancer risk (21-35). In our study, the serum concentration of IGFBP3 did not have a prognostic impact nor serve as a surrogate marker for the effectiveness of gefitinib therapy. From a biological perspective, IGFBPs inhibit IGF1 action by competitive binding, which reduces bioavailability. However, in some cases, IGFBP3 acts independently and may both blockade the cell cycle and induce apoptosis (48). In the presence of IGFBP protease, IGFBP3 also has the ability to stimulate the growth of cancer cells (49). These dual regulatory effects of IGFBP3 on IGF-I may explain our study.

The limitations of our study include a small sample size, the heterogeneity of the treatment regimens, and the 
retrospective nature of the study. We were able to show associations between the concentration of IGF1 and both response to gefitinib treatment and prognosis. However, the cut-off level of IGF1 differed for these findings. Only a prospective study with more strict criteria for the selection of cases could settle these limitations.

In conclusion, we demonstrated that the status of serum IGF is a predictive factor for response to gefitinib therapy independent of EGFR mutational status. In addition, we found that having IGF1-positive serum and having wild-type EGFR were independent negative prognostic factors in patients with non-squamous NSCLC. In the future, the therapy of choice for patients with advanced NSCLC may be inhibiting IGF1 combined with EGFR-TKIs regardless of EGFR mutation status.

\section{References}

1. Chou TY, Chiu CH, Li LH, et al: Mutation in the tyrosine kinase domain of epidermal growth factor receptor is a predictive and prognostic factor for gefitinib treatment in patients with non-small cell lung cancer. Clin Cancer Res 11: 3750-3757, 2005.

2. Huang SF, Liu HP, Li LH, et al: High frequency of epidermal growth factor receptor mutations with complex patterns in non-small cell lung cancers related to gefitinib responsiveness in Taiwan. Clin Cancer Res 10: 8195-8203, 2004

3. Shigematsu H, Lin L, Takahashi T, et al: Clinical and biological features associated with epidermal growth factor receptor gene mutations in lung cancers. J Natl Cancer Inst 97: 339-346, 2005.

4. Tokumo M, Toyooka S, Kiura K, et al: The relationship between epidermal growth factor receptor mutations and clinicopathologic features in non-small cell lung cancers. Clin Cancer Res 11: 1167-1173, 2005

5. Ramalingam SS, Dahlberg SE, Langer CJ, et al: Outcomes for elderly, advanced-stage non-small cell lung cancer patients treated with bevacizumab in combination with carboplatin and paclitaxel: analysis of Eastern Cooperative Oncology Group Trial 4599. J Clin Oncol 26: 60-65, 2008.

6. Fukuoka M, Yano S, Giaccone G, et al: Multi-institutional randomized phase II trial of gefitinib for previously treated patients with advanced non-small-cell lung cancer (The IDEAL 1 Trial) [corrected]. J Clin Oncol 21: 2237-2246, 2003.

7. Bell DW, Lynch TJ, Haserlat SM, et al: Epidermal growth factor receptor mutations and gene amplification in non-small-cell lung cancer: molecular analysis of the IDEAL/INTACT gefitinib trials. J Clin Oncol 23: 8081-8092, 2005.

8. Cappuzzo F, Finocchiaro G, Metro G, et al: Clinical experience with gefitinib: an update. Crit Rev Oncol Hematol 58: 31-45, 2006.

9. Cortes-Funes H, Gomez C, Rosell R, et al: Epidermal growth factor receptor activating mutations in Spanish gefitinib-treated non-small cell lung cancer patients. Ann Oncol 16: 1081-1086, 2005.

10. Han SW, Kim TY, Hwang PG, et al: Predictive and prognostic impact of epidermal growth factor receptor mutation in nonsmall-cell lung cancer patients treated with gefitinib. J Clin Oncol 23: 2493-2501, 2005.

11. Hirsch FR, Varella-Garcia M, McCoy J, et al: Increased epidermal growth factor receptor gene copy number detected by fluorescence in situ hybridization associates with increased sensitivity to gefitinib in patients with bronchioloalveolar carcinoma subtypes: a Southwest Oncology Group Study. J Clin Oncol 23: 6838-6845, 2005.

12. Kim KS, Jeong JY, Kim YC, et al: Predictors of the response to gefitinib in refractory non-small cell lung cancer. Clin Cancer Res 11: 2244-2251, 2005.

13. Lynch TJ, Bell DW, Sordella R, et al: Activating mutations in the epidermal growth factor receptor underlying responsiveness of non-small-cell lung cancer to gefitinib. N Engl J Med 350: 2129-2139, 2004

14. Paez JG, Janne PA, Lee JC, et al: EGFR mutations in lung cancer: correlation with clinical response to gefitinib therapy. Science 304: 1497-1500, 2004
15. Rosell R, Ichinose Y, Taron M, et al: Mutations in the tyrosine kinase domain of the EGFR gene associated with gefitinib response in non-small-cell lung cancer. Lung Cancer 50: 25-33, 2005.

16. Sonobe M, Manabe T, Wada H and Tanaka F: Mutations in the epidermal growth factor receptor gene are linked to smokingindependent, lung adenocarcinoma. Br J Cancer 93: 355-363, 2005.

17. Takano T, Ohe Y, Sakamoto H, et al: Epidermal growth factor receptor gene mutations and increased copy numbers predict gefitinib sensitivity in patients with recurrent non-small cell lung cancer. J Clin Oncol 23: 6829-6837, 2005.

18. Tomizawa Y, Iijima H, Sunaga N, et al: Clinicopathologic significance of the mutations of the epidermal growth factor receptor gene in patients with non-small cell lung cancer. Clin Cancer Res 11: 6816-6822, 2005.

19. Yu H and Rohan T: Role of the insulin-like growth factor family in cancer development and progression. J Natl Cancer Inst 92: 1472-1489, 2000.

20. Furstenberger $G$ and Senn HJ: Insulin-like growth factors and cancer. Lancet Oncol 3: 298-302, 2002.

21. Hankinson SE, Willett WC, Colditz GA, et al: Circulating concentrations of insulin-like growth factor-I and risk of breast cancer. Lancet 351: 1393-1396, 1998.

22. Bruning PF, Van Doorn J, Bonfrer JM, et al: Insulin-like growth-factor-binding protein 3 is decreased in early-stage operable pre-menopausal breast cancer. Int J Cancer 62: 266-270, 1995.

23. Peyrat JP, Bonneterre J, Hecquet B, et al: Plasma insulin-like growth factor-1 (IGF-1) concentrations in human breast cancer. Eur J Cancer 29: 492-497, 1993.

24. Chan JM, Stampfer MJ, Giovannucci E, et al: Plasma insulinlike growth factor-I and prostate cancer risk: a prospective study. Science 279: 563-566, 1998.

25. Chan JM, Stampfer MJ, Ma J, et al: Insulin-like growth factor-I (IGF-I) and IGF binding protein-3 as predictors of advanced-stage prostate cancer. J Natl Cancer Inst 94: 1099-1106, 2002.

26. Wolk A, Mantzoros CS, Andersson SO, et al: Insulin-like growth factor 1 and prostate cancer risk: a population-based, case-control study. J Natl Cancer Inst 90: 911-915, 1998.

27. Wei EK, Ma J, Pollak MN, et al: C-peptide, insulin-like growth factor binding protein-1, glycosylated hemoglobin, and the risk of distal colorectal adenoma in women. Cancer Epidemiol Biomarkers Prev 15: 750-755, 2006.

28. Wei EK, Ma J, Pollak MN, et al: A prospective study of C-peptide, insulin-like growth factor-I, insulin-like growth factor binding protein-1, and the risk of colorectal cancer in women. Cancer Epidemiol Biomarkers Prev 14: 850-855, 2005.

29. Ma J, Pollak MN, Giovannucci E, et al: Prospective study of colorectal cancer risk in men and plasma levels of insulin-like growth factor (IGF)-I and IGF-binding protein-3. J Natl Cancer Inst 91: 620-625, 1999.

30. Lukanova A, Lundin E, Toniolo P, et al: Circulating levels of insulin-like growth factor-I and risk of ovarian cancer. Int J Cancer 101: 549-554, 2002.

31. Lukanova A, Lundin E, Micheli A, et al: Risk of ovarian cancer in relation to prediagnostic levels of C-peptide, insulin-like growth factor binding proteins-1 and -2 (USA, Sweden, Italy). Cancer Causes Control 14: 285-292, 2003.

32. Wolpin BM, Michaud DS, Giovannucci EL, et al: Circulating insulin-like growth factor axis and the risk of pancreatic cancer in four prospective cohorts. Br J Cancer 97: 98-104, 2007.

33. Wolpin BM, Michaud DS, Giovannucci EL, et al: Circulating insulin-like growth factor binding protein-1 and the risk of pancreatic cancer. Cancer Res 67: 7923-7928, 2007.

34. Michaud DS, Wolpin B, Giovannucci E, et al: Prediagnostic plasma C-peptide and pancreatic cancer risk in men and women. Cancer Epidemiol Biomarkers Prev 16: 2101-2109, 2007.

35. Schumacher FR, Cheng I, Freedman ML, et al: A comprehensive analysis of common IGF1, IGFBP1 and IGFBP3 genetic variation with prospective IGF-I and IGFBP-3 blood levels and prostate cancer risk among Caucasians. Hum Mol Genet 19: 3089-3101, 2010.

36. Carboni JM, Wittman M, Yang Z, et al: BMS-754807, a small molecule inhibitor of insulin-like growth factor-1R/IR. Mol Cancer Ther 8: 3341-3349, 2009. 
37. Clemens PL, Park JS and Cohen MB: BMS-754807, an oral dual IGF-IR/IR inhibitor: first-in-human single-dose study of safety, tolerability, pharmacokinetics, and pharmacodynamics in healthy subjects. Proceedings of the AACR-NCI-EORTC International Conference November 15-19, Boston, MA. Mol Cancer Ther 8 (Suppl. 1): A101, 2009.

38. Desai J, Solomon B and Davis ID: Phase I dose-escalation study of daily BMS-754807, an oral, dual IGF-1R/insulin receptor (IR) inhibitor in subjects with solid tumors. J Clin Oncol 28: 15s, 2010.

39. Nagai Y, Miyazawa H, Huqun, et al: Genetic heterogeneity of the epidermal growth factor receptor in non-small cell lung cancer cell lines revealed by a rapid and sensitive detection system, the peptide nucleic acid-locked nucleic acid PCR clamp. Cancer Res 65: 7276-7282, 2005.

40. Kosaka T, Yatabe Y, Endoh H, Kuwano H, Takahashi T and Mitsudomi T: Mutations of the epidermal growth factor receptor gene in lung cancer: biological and clinical implications. Cancer Res 64: 8919-8923, 2004.

41. Chakravarti A, Loeffler JS and Dyson NJ: Insulin-like growth factor receptor I mediates resistance to anti-epidermal growth factor receptor therapy in primary human glioblastoma cells through continued activation of phosphoinositide 3-kinase signaling. Cancer Res 62: 200-207, 2002.

42. Buck E, Eyzaguirre A, Rosenfeld-Franklin M, et al: Feedback mechanisms promote cooperativity for small molecule inhibitors of epidermal and insulin-like growth factor receptors. Cancer Res 68: 8322-8332, 2008
43. Huang F, Greer A, Hurlburt W, et al: The mechanisms of differential sensitivity to an insulin-like growth factor-1 receptor inhibitor (BMS-536924) and rationale for combining with EGFR/HER2 inhibitors. Cancer Res 69: 161-170, 2009.

44. Werner H and Le Roith D: New concepts in regulation and function of the insulin-like growth factors: implications for understanding normal growth and neoplasia. Cell Mol Life Sci 57: 932-942, 2000.

45. Yu H, Spitz MR, Mistry J, Gu J, Hong WK and Wu X: Plasma levels of insulin-like growth factor-I and lung cancer risk: a case-control analysis. J Natl Cancer Inst 91: 151-156, 1999.

46. Lukanova A, Toniolo $\mathrm{P}$, Akhmedkhanov A, et al: A prospective study of insulin-like growth factor-I, IGF-binding proteins-1, -2 and -3 and lung cancer risk in women. Int J Cancer 92: 888-892, 2001.

47. Lin Y, Tamakoshi A, Kikuchi S, et al: Serum insulin-like growth factor-I, insulin-like growth factor binding protein-3, and the risk of pancreatic cancer death. Int J Cancer 110: 584-588, 2004.

48. Baxter RC: Signalling pathways involved in antiproliferative effects of IGFBP-3: a review. Mol Pathol 54: 145-148, 2001

49. Haq M, Shaeii AE, Zervos EE and Rosemurgy AS: In vitro and in vivo matrix metalloproteinase production by pancreatic cancer cells and by distant organs. Int J Surg Investig 1: 459-465, 2000 . 